\title{
Penerapan Layanan Klasikal Terhadap Kemandirian dalam Perencanaan Memilih Karir Peserta Didik
}

\author{
Silvia Mayang Sari ${ }^{1 凶}$, Joni Adison ${ }^{1}$, Suryadi $^{1}$ \\ (1) Bimbingan Konseling Islam, STKIP PGRI Sumatera Barat
}

$\triangle$ Corresponding author

(silviamayangsari1605@gmail.com)

\begin{abstract}
Abstrak
Penelitian ini dilatar belakangi masih ada peserta didik yang belum memahami tentang karir, masih ada peserta didik yang belum peduli dengan karir, masih ada peserta didik yang belum bisa memilih karir, masih ada peserta didik yang belum mengetahui potensinya. Mendeskripsikan pemilihan karir berdasarkan kepercayaan diri, mendeskripsikan pemilihan karir berdasarkan tanggung jawab. Jenis penelitian ini merupakan penelitian deskriptif kuantitatif. Populasi penelitian sebanyak 102 yang dipilih dengan teknik cluster random sampling sebanyak 51 sampel peserta didik. Instrumen yang digunakan yaitu angket. Sedangkan untuk analisis data menggunakan interval skor. Hasil penelitian tentang penerapan layanan klasikal terhadap kemandirian dalam perencanaan memilih karir di SMA N 4 Pariaman yaitu 1) secara keseluruhan berada pada kategori tinggi 2) indikator percaya diri berada pada kategori tinggi 3) indikator tanggung jawab berada pada kategori tinggi 4) indikator mengarahkan dan mengembangkan diri berada pada kategori tinggi 5) pada indikator tekun, inisiatif dan kreatif berada pada kategori tinggi 6) indikator berkeinginan mengerjakan sesuatu tanpa bantuan orang lain berada pada kategori tinggi. Berdasarkan hasil penelitian dapat direkomendasikan kepada peserta didik agar dapat lebih meningkatkan kemandirian dalam perencanaan memilih karir untuk masa depan.
\end{abstract}

Kata Kunci: Layanan klasikal, kemandirian, perencanaan memilih karir.

\section{Abstract}

The background of this research is that there are still students who do not understand about careers, there are still students who do not care about careers, there are still students who cannot choose a career, there are still students who do not know their potential. Describing career choices based on self-confidence, describing career choices based on responsibility. This type of research is a quantitative descriptive research. The research population was 102 which were selected by using cluster random sampling technique as many as 51 samples of students. The instrument used is a questionnaire. Meanwhile, for data analysis using score intervals. The results of the study on the application of classical services to independence in planning to choose a career at SMA N 4 Pariaman are 1) overall in the high category 2) the confidence indicator is in the high category 3) the responsibility indicator is in the high category 4) directing and developing indicators self is in the high category 5) the indicators of perseverance, initiative and creativity are in the high category 6) the indicator of wanting to do something without the help of others is in the high category. Based on the results of the study, it can be recommended to students in order to further increase their independence in planning for choosing a career for the future.

Keywords: Classical service, independence, planning to choose a career.

\section{PENDAHULUAN}

Pendidikan adalah usaha untuk mengembangkan dan membina kepribadian yang dimiliki manusia dalam mendewasakan diri melalui pengajaran dan latihan. Undang-Undang Sistem pendidikan No. 20 Tahun 2003 adalah usaha sadar dan terencana untuk mewujudkan suasana belajar dan proses pembelajaran agar peserta didik secara aktif mengembangkan potensi dirinya untuk memiliki kekuatan spiritual keagamaan, pengendalian diri, kepribadian, kecerdasan, akhlak mulia, serta keterampilan yang diperlukan dirinya dan masyarakat ( Neolaka, 2017:2). 
Slameto (Hamdu 2011:82) mengemukakan bahwa belajar adalah serangkaian kegiatan jiwa raga untuk memperoleh suatu perubahan tingkah laku sebagai hasil dari pengalaman individu dalam interaksi dengan lingkungannya menyangkut kognitif, afektif, dan psikomotor. Dalam belajar, peserta didik mengalami sendiri proses dari tidak tahu menjadi tahu. Mohamad Surya (Hamdu 2011:82) mengungkapkan bahwa pembelajaran merupakan suatu proses perubahan yaitu perubahan perilaku sebagai hasil interaksi antara dirinya dan lingkungannya dalam memenuhi kebutuhan hidupnya. Suprihatin (2015:74) proses belajar pada manusia dapat dirumuskan sebagai suatu aktivitas mental atau psikis yang berlangsung dalam interaksi aktif dengan lingkungan yang menghasilkan perubahan-perubahan dalam pengetahuan dan nilai sikap. Muhibbin Syah (Cleopatra 2015:174) berpendapat bahwa belajar merupakan tahapan perubahan seluruh tingkah laku individu yang relatif menetap sebagai hasil pengalaman dan interaksi dengan lingkungan yang melibatkan proses kognitif.

Menurut Hadiwinarto (2019:124) Layanan format klasikal adalah salah satu bentuk/format layanan bimbingan dan konseling dengan sasaran peserta didik yang terhimpun dalam satu kelas (satu rombongan belajar). Sari ( 2020:111) kegiatan layanan bimbingan klasikal bertujuan membantu peserta didik/konseli dapat mencapai kemandirian dalam kehidupannya, perkembangan yang utuh dan optimal dalam bidang pribadi, sosial, belajar, dan karir, serta mencapai keselarasan antara pikiran, perasaan dan perilaku.

Kesuksesan seseorang dalam berkarir tidak terlepas dari pendidikan. pendidikan memiliki tujuan yaitu mengembangkan potensi yang ada dalam diri peserta didik agar lebih optimal sehingga dapat menjadikan peserta didik menjadi pribadi yang berkualitas dan memiliki pengetahuan serta keterampilan sebagai persiapan untuk melanjutkan kehidupan yang lebih baik di masa depan. Yusuf (Febriani, 2016:160) mengungkapkan pendidikan merupakan pre-occupation, dimana pendidikan adalah awal penentuan karir seseorang. Pendidikan juga merupakan unsur utama dari usaha seseorang dalam membina, mematangkan persiapan pilihan jenis karir serta menyusun rencana karir tertentu. Karir sangat berkaitan dengan perkembangan personal seseorang dan menjadi bagian penting dalam kesuksesan hidup seseorang kedepannya terutama bagi seorang peserta didik.

Peserta didik adalah generasi muda dan generasi penerus bangsa. Mereka perlu dipersiapkan secara matang untuk menjadi generasi yang mampu untuk meneruskan bangsa. Kemampuankemampuan yang dimiliki peserta didik harus dipupuk dan diasah melalui usaha mendampingi karirnya. Agar peserta didik semakin paham dengan dirinya, lingkungan hidupnya, proses pengambilan keputusan dan makin mantap dalam mempersiapkan diri dalam hal ilmu pengetahuan, keterampilan, nilai dan sikap.

Menurut Hartono (2016:28) Bimbingan karir merupakan pelayanan dan aktivitas-aktivitas yang dimaksudkan untuk membantu para individu, pada semua usia dan sepanjang rentang kehidupan mereka, untuk memilih pendidikan, pelatihan dan pilihan karir serta mengelola karir-karir mereka. Menurut Munandir (Hartono 2016:29) bimbingan karir adalah proses membantu peserta didik/konseli dalam hal memahami dirinya, memahami lingkungannya khususnya lingkungan berupa dunia kerja, menentukan pilihan kerja, dan akhirnya membantunya menyusun rencana untuk mewujudkan keputusan yang diambilnya.

Jadi bimbingan karir adalah proses bantuan yang diberikan oleh guru BK/konselor kepada klien/peserta didik agar klien/peserta didik mampu mencapai pemahaman diri, pemahaman karir, dan mampu memperoleh kemandirian dalam pengambilan keputusan karir serta dapat meraih dan mempertahankan karirnya di kehidupan bermasyarakat.

Menurut Mardiyati (2015:33) karir adalah sebuah rangkaian peristiwa yang terjadi sepanjang hidup seseorang, dimana didalamnya terlibat berbagai jenis pekerjaan dan peran yang dimiliki olehnya. Menurut Yendrawati (2007:178) karir umumnya diartikan sebagai ide untuk terus bergerak ke atas dalam garis pekerjaan seseorang. bergerak ke atas berarti berhak atas pendapatan yang lebih besar, serta mendapatkan status, prestise dan kuasa yang lebih besar. Meskipun biasa dibatasi pada garis pekerjaan yang menghasilkan uang. Dengan demikian karir terdiri dari urutan pengalaman atau suatu rangkaian kerja yang dipegang selama kehidupan seseorang yang memberikan kesinambungan, ketentraman, dan harapan untuk maju sehingga menciptakan sikap dan perilaku tertentu. 
Dalam pemilihan karir peserta didik harus tahu terlebih dahulu potensi apa yang dimilikinya, selain itu peserta didik juga memilih karir berdasarkan minatnya. Akan tetapi tidak semua peserta didik yang tau dengan potensi dirinya, sehingga dengan begitu peserta didik menjadi kesulitan dalam menentukan karir yang baik untuk dirinya. Banyak peserta didik yang memilih karir dengan asal seperti mengikuti apa yang dipilih temannya, mengikuti kemauan orang tua, dan lainnya sehingga nantinya apa yang dipilih tidak sesuai dengan potensi diri dan minat peserta didik tersebut. Selain itu ada juga peserta didik yang tidak paham apa itu karir dan arah tujuan karir di masa depan itu kemana sehingga dengan begitu peserta didik menjadi bingung dengan pemilihan karir. Rendahnya pemahaman dan gambaran mengenai yang akan dilakukan adalah problem karir peserta didik. Pemahaman dan gambaran mengenai karir sangat diperlukan oleh peserta didik setidaknya peserta didik harus mengetahui dan memahami dasar-dasar mengenai karir agar peserta didik bisa memilih karirnya dengan tepat.

Menurut Hartono (2016:59) kemandirian memilih karir ditandai oleh lima ciri sebagai kriterianya, yaitu: a) percaya diri, b) tanggung jawab, c) Mengarahkan dan Mengembangkan Diri, d) tekun, inisiatif, dan kreatif, e) Berkeinginan Mengerjakan Sesuatu Tanpa Bantuan Orang Lain. Jadi dapat saya simpulkan bahwa karir sangat penting untuk diperkenalkan kepada anak mulai dari kecil, agar anak dapat memahami mengenai karir. Di sekolah dari mulai SD, SMP, SMA dan perguruan tinggi hingga pekerjaan dan posisi jabatan, berarti di setiap waktu, setiap jenjang pendidikan dan kehidupan adalah bagian dari karir. dengan itu peserta didik pada umumnya melewati masa karir untuk mencapai masa depan yang baik. Dengan demikian bisa disebut karir adalah bagian dari kehidupan yang penting dan harus dipertimbangan dengan matang dalam penentuannya.

Berdasarkan dari observasi yang dilakukan oleh peneliti pada 16 April 2021 di SMA N 4 Pariaman, terdapat permasalahan-permasalahan karir yang dialami oleh peserta didik, yaitu peserta didik yang belum memahami tentang karir, peserta didik yang belum peduli dengan karir, peserta didik yang belum bisa memilih karir.

Berdasarkan hasil wawancara yang dilakukan peneliti dengan peserta didik dan guru BK pada 16 April 2021 di SMA N 4 Pariaman, terdapat permasalahan-permasalahan karir yang dialami oleh peserta didik, yaitu peserta didik yang belum mengetahui potensinya, peserta didik yang belum termotivasi untuk mengenal karir, peserta didik yang belum menentukan cita-cita, dan peserta didik yang belum percaya diri dengan potensi yang dimilikinya, peserta didik yang memilih karirnya mengikuti teman, peserta didik yang memilih karir berdasarkan keinginan orang tua, peserta didik yang belum bisa mengembangkan bakat dan minatnya, peserta didik yang ragu dengan jurusan yang dipilih.

Berdasarkan hasil observasi dan wawancara yang sudah dilakukan peneliti lakukan maka peneliti tertarik untuk melakukan penelitian dengan judul "Penerapan Layanan Klasikal Terhadap Kemandirian dalam Perencanaan Memilih Karir di SMA N 4 Pariaman".

\section{METODE PENELITIAN}

Jenis dari penelitian ini yaitu deskriptif kuantitatif. Yaitu mendeskripsikan gejala-gejala, aktivitas yang ada dalam suatu kelompok.Menurut Andih (2018:78) penelitian deskriptif kuantitatif yaitu menggambarkan sesuatu secara langsung saat melakukan penelitian dan memeriksa gejala tertentu serta sebab-sebab saat melakukan penelitian. Sedangkan menurut Zellatifanny \& Mudjiyanto (2018:84) ada beberapa tujuan penelitian deskriptif kuantitatif : deskripsi tentang ciriciri atau gejala yang berhubungan dengan populasi tertentu, perkiraan tentang proporsi populasi yang memiliki ciri-ciri tersebut. Berdasarkan teori tersebut peneliti akan mendeskripsikan mengenai permasalahan Kemandirian Memilih karir di SMA N 4 Pariaman.

Penelitian ini menggunakan teknik pengambilan sampel simple random sampling. Menurut Riduwan (2010: 58) simple random sampling merupakan teknik pengambilan sampel yang dilakukan secara acak tanpa memperhatikan strata yang ada dalam populasi tersebut. Menurut Arikunto (2006:177) simple random sampling adalah teknik sampling yang di dalam pengambilan sampelnya, peneliti mencampur subjek didalam populasi jadi semua subjek dianggap sama. 


\section{HASIL DAN PEMBAHASAN}

\section{Permasalahan Kemandirian dalam Perencanaan Memilih Karir}

Berdasarkan hasil penelitian ditemukan bahwa penerapan layanan klasikal terhadap kemandirian dalam perencanaan memilih karir peserta didik di SMA N 4 Pariaman dari 51 responden terdapat 11 peserta didik dengan persentase $21,57 \%$ berada di kategori sangat tinggi, kemudian 34 peserta didik dengan persentase $66,67 \%$ berada di kategori tinggi, selanjutnya 6 peserta didik dengan persentase $11,76 \%$ berada dikategori cukup tinggi, lalu tidak terdapat peserta didik yang berada pada kategori rendah dan sangat rendah dalam hal permasalahan kemandirian dalam perencanaan memilih karir.

Menurut Frank Person (Winkel \& Hastuti 2010:408) Perencanaan karir adalah suatu cara untuk membantu peserta didik dalam memilih suatu bidang karir yang sesuai dengan potensi mereka, sehingga cukup cukup berhasil di bidang pekerjaan. Perencanaan karir diperlukan persiapan yang matang sebelum peserta didik terjun secara langsung dalam dunia karir. Perencanaan karir adalah sesuatu yang didasari atas potensi yang dimiliki peserta didik sehingga tidak menimbulkan pertentangan antara karir yang dipilih dengan potensi yang ada pada diri peserta didik.

\section{Deskripsi Permasalahan Perencanaan Karir Dari Indikator Percaya Diri}

Berdasarkan hasil penelitian ditemukan bahwa penerapan layanan klasikal terhadap kemandirian dalam perencanaan memilih karir peserta didik di SMA N 4 Pariaman berdasarkan indkator percaya diri dari 51 responden dari indikator percaya diri terdapat 14 peserta didik dengan persentase $27,45 \%$ berada pada kategori sangat tinggi, kemudian 24 peserta didik dengan persentase $47,06 \%$ berada pada kategori tinggi, selanjutnya 13 peserta didik dengan persentase 25,49\% berada pada kategori cukup tinggi, lalu tidak terdapat peserta didik yang berada pada kategori rendah dan sangat rendah dalam percaya diri.

Hartono (2016:59) Percaya diri sebagai kriteria kemandirian pengambilan keputusan karir mencakup tataran pengenalan, akomodasi, dan tindakan. Pada tataran pengenalan, seseorang mempelajari potensi dirinya, ragam pekerjaan atau profesi, pendidikan dan peluang yang terarah pada pemilihan karir. Pada tataran akomodasi terjadi internalisasi nilai-nilai yang melandasi keyakinan atas potensi dan keterampilannya yang diperlukan dalam memilih karir. adapun pada tahap tindakan, seseorang telah menanamkan rasa percaya diri, sehingga ia merasa mampu memilih, meraih, dan mempertahankan karirnya dalam kehidupan mendatang.

\section{Deskripsi Permasalahan Perencanaan Karir dari Indikator Tanggung Jawab}

Berdasarkan hasil penelitian ditemukan bahwa penerapan layanan klasikal terhadap kemandirian dalam perencanaan memilih karir peserta didik di SMA N 4 Pariaman berdasarkan indkator tanggung jawab dari 51 responden dari indikator tanggung jawab terdapat 21 peserta didik dengan persentase $41,18 \%$ berada pada kategori sangat tinggi, kemudian 27 peserta didik dengan persentase $52,94 \%$ berada pada kategori tinggi, selanjutnya 3 peserta didik dengan persentase $5,88 \%$ berada pada kategori cukup tinggi, lalu tidak terdapat peserta didik yang berada pada kategori rendah dan sangat rendah dalam tanggung jawab.

Hartono (2016:59) Memiliki rasa tanggung jawab sebagai kriteria kemandirian pengambilan keputusan karir mencakup tataran pengenalan, akomodasi, dan tindakan. Pada tataran pengenalan, seseorang belajar sebagai individu yang memiliki tanggung jawab memilih karir, meraih karir, dan mempertahankan karirnya di dalam kehidupan bermasyarakat mendatang. Pada tataran akomodasi terjadi proses penerimaan nilai-nilai pengembangan karir, sedangkan pada tataran tindakan seseorang mengembangkan rasa tanggung jawab sebagai individu yang mampu memilih, meraih, dan mempertahankan karir di dalam kehidupan bermasyarakat.

\section{Deskripsi Permasalahan Perencanaan Karir dari Indikator Mengarahkan dan Mengembangkan Diri}

Berdasarkan hasil penelitian ditemukan bahwa penerapan layanan klasikal terhadap kemandirian dalam perencanaan memilih karir peserta didik di SMA N 4 Pariaman berdasarkan indkator mengarahkan dan mengembangkan diri dari 51 responden dari indikator mengarahkan dan 
mengembangkan diri terdapat 9 peserta didik dengan persentase 17,65\% berada pada kategori sangat tinggi, kemudian 21 peserta didik dengan persentase 41,18\% berada pada kategori tinggi, selanjutnya 21 peserta didik dengan persentase 41,18\% berada pada kategori cukup tinggi, lalu tidak terdapat peserta didik yang berada pada kategori rendah dan sangat rendah dalam mengarahkan dan mengembangkan diri.

Sesuai dengan penelitian diatas konsisten dengan teori yang dikemukakan oleh Hartono (2016:59) Mengarahkan dan mengembangkan diri sebagai kriteria kemandirian pengambilan keputusan karir juga mencakup tataran pengenalan, akomodasi, dan tindakan. Pada tataran pengenalan, seseorang mampu menerima secara utuh hasil pemahaman diri dan pemahaman karirnya, ia sanggup mencari berbagai informasi yang berkaitan dengan aktivitas pengembangan diri dan pengambangan karirnya. Pada tataran akomodasi, seseorang tertarik melakukan berbagai aktivitas pengembangan diri berdasarkan arah pemilihan karirnya, sedangkan pada tataran tindakan, seseorang melakukan berbagai aktivitas pengembangan diri ke arah pemilihan karir yang diinginkan.

\section{Deskripsi Permasalahan Perencanaan Karir dari Indikator Tekun, Inisiatif dan Kreatif}

Berdasarkan hasil penelitian ditemukan bahwa penerapan layanan klasikal terhadap kemandirian dalam perencanaan memilih karir peserta didik di SMA N 4 Pariaman berdasarkan indkator tekun, inisiatif dan kreatif dari 51 responden dari indikator tekun, inisiatif dan kreatif terdapat 15 peserta didik dengan persentase 29,41\% berada pada kategori sangat tinggi, kemudian 29 peserta didik dengan persentase $56,86 \%$ berada pada kategori tinggi, selanjutnya 6 peserta didik dengan persentase 11,76\% berada pada kategori cukup tinggi, kemudian 1 peserta didik dengan persentase $1,96 \%$ berada pada kategori rendah, lalu tidak terdapat peserta didik yang berada pada kategori sangat rendah dalam tekun, inisiatif dan kreatif.

Sesuai dengan penelitian diatas konsisten dengan teori yang dikemukakan oleh Hartono (2016:59) seseorang yang mandiri dalam melakukan pengambilan keputusan karir memiliki perilaku tekun, inisiatif, dan kreatif. Perilaku ini mencakup tiga tataran, yaitu tataran pengenalan, akomodasi, dan tindakan. Pada tataran pengenalan, seseorang mempelajari cara menumbuhkan perilaku tekun, cara menumbuhkan perilaku inisiatif, dan cara menumbuhkan perilaku kreatif dalam pengambilan keputusan karir. Adapun pada tataran akomodasi seseorang telah menyadari bahwa perilaku tekun, inisiatif dan kreatif sangat diperlukan untuk menunjang proses pengambilan keputusan karir. Pada tataran tindakan, seseorang mampu menunjukan perilaku tekun, inisiatif dan kreatif dalam usaha mengambangkan strategi pengambilan keputusan karirnya.

\section{Deskripsi Permasalahan Perencanaan Karir dari Indikator Berkeinginan Mengerjakan Sesuatu Tanpa Bantuan Orang Lain}

Berdasarkan hasil penelitian ditemukan bahwa penerapan layanan klasikal terhadap kemandirian dalam perencanaan memilih karir peserta didik di SMA N 4 Pariaman berdasarkan indkator mengerjakan sesuatu tanpa bantuan orang lain dari 51 responden dari indikator berkeinginan mengerjakan sesuatu tanpa bantuan orang lain terdapat 8 peserta didik dengan persentase $15,69 \%$ berada pada kategori sangat tinggi, kemudian 26 peserta didik dengan persentase $50,98 \%$ berada pada kategori tinggi, selanjutnya 12 peserta didik dengan persentase 23,53\% berada pada kategori cukup tinggi, kemudian 5 peserta didik dengan persentase 9,80\% berada pada kategori rendah, lalu tidak terdapat peserta didik yang berada pada kategori sangat rendah dalam berkeinginan mengerjakan sesuatu tanpa bantuan orang lain.

Sesuai dengan penelitian diatas konsisten dengan teori yang dikemukakan oleh Hartono (2016:59) di samping memiliki keempat ciri yang telah dipaparkan di atas, seseorang yang memiliki kemandirian dalam pengambilan keputusan karir juga mempunyai keinginan kuat untuk melakukan perbuatan tanpa bantuan orang lain. Perilaku ini mencakup tiga tataran yaitu, tataran pengenalan, akomodasi, dan tindakan. Pada tataran pengenalan, seseorang belajar mengenal, memahami, dan menerima perangkat kemampuan dan keterampilan diri yang dibutuhkan untuk melakukan proses pengambilan keputusan karir. Sedangkan pada tataran akomodasi, seseorang menyadari atas kemampuan dan keterampilannya yang diperlukan dalam pengambilan keputusan karir. Pada 
tataran tindakan, mampu melakukan strategi pengambilan keputusan karir, berdasarkan pemahaman diri dan pemahaman karir serta peluang yang ada.

\section{KESIMPULAN}

Berdasarkan hasil penelitian yang sudah dilakukan tentang permasalahan kemandirian dalam perencanaan memilih karir peserta didik XI IPS SMA N 4 Pariaman berada pada kategori Tinggi, dapat diambil kesimpulan yaitu: Mendeskripsikan masalah karir yang terlihat dalam 5 indikator yaitu: a) percaya diri berada pada kategori tinggi, b) tanggung jawab berada pada kategori tinggi, c) mengarahkan dan mengembangan diri berada pada kategori tinggi, d) tekun, inissiatif, kreatif berada pada kategori tinggi, e) berkeinginan mengerjakan sesuatu tanpa bantuan orang lain berada pada kategori tinggi.

\section{DAFTAR RUJUKAN}

Andih, D. C. 2018. Peran Media Sosial ( Facebook, Instagram, Youtube ) Dalam Menarik Attractions Tetempangan Hill is one tourist attraction that is booming and become an idol for. 13(1), 7480.

Arikunto, S. 2006. Metode Penelitian Kualitatif. Jakarta: Bumi Aksara.

Hamdu, Ghullam,Dkk. 2011. Pengaruh Motivasi Belajar Peserta didik Terhadap Prestasi Belajar IPA di Sekolah Dasar. Jurnal Penelitian Pendidikan. 12(1), 81-86.

Hartono. 2016. Bimbingan Karier. Jakarta: Kencana.

Mardiyati, Baiqi Dini. 2015. Perbedaan Adaptabilitas Karir di Tinjau dari Jenis Sekolah (SMA dan SMK). Jurnal Fakultas Psikologi. 3(1), 31-41.

Neolaka, Amos,Dkk. 2017. Landasan Pendidikan Dasar Pengenalan Diri Sendiri Menuju Perubahan Hidup. Depok: Kencana.

Prayitno, Erman Amti. 2004. Dasar-dasar Bimbingan dan Konseling. Jakarta: Rineka Cipta

Riduwan, A. 2010. Metode Penelitian untuk Guru-Karyawan dan Peneliti Pemula. Alfabeta.

Sari, Nina Permata, Dkk. 2020. Bimbingan dan Konseling Perspektif Indigenous: Etnik Banjar. Yogyakarta: CV Budi Utama.

Suprihatin, Siti. 2015. Upaya Guru Dalam Meningkatkan Motivasi Belajar Peserta didik. Jurnal Pendidikan Ekonomi UM Metro. 3(1),73-82.

Yusuf, Syamsu dan Nurihsan, A. Juntika. 2005. Landasan Bimbingan \& Konseling. Bandung: Remaja Rosdakarya.

Yusuf, Syamsu dan Nurihsan, J. 2012 Landasan Bimbingan \& Konseling. Bandung: Remaja Rosdakarya.

Zellatifanny, C. M., \& Mudjiyanto, B. 2018. Tipe Penelitian Deskripsi Dalam Ilmu Komunikasi. Diakom : Jurnal Media Dan Komunikasi, 1(2), 83-90. 